\title{
Comparison of different methods of producing bambara (Voandzeia subterranean L. Thou) flours for preparation of 'moin-moin'
}

\author{
Olapade A. ${ }^{1^{*}}$ and Adetuyi D. O. ${ }^{2}$ \\ 1.Department of Food Technology, Faculty of Technology, \\ University of Ibadan, Ibadan, Nigeria \\ 2. Federal Institute of Industrial Research, \\ Oshodi, PMB 21023, Ikeja, Lagos, Nigeria. \\ * Address for correspondence Email:aa.olapade@mail.ui.edu.ng,aaolapade@yahoo.com
}

\begin{abstract}
Bambara nut was subjected to different treatments prior to mechanical dry dehulling and milling into flours. Physicochemical properties of the flours and sensory attributes of moin-moin prepared from the flours were compared with that of moin-moin from fresh pastes from cowpea and Bambara. The functional properties investigated included foam-ability, foam-stability, gelation capacity, dispersibility and dehull-ability while proximate chemical composition

water steeping of Bambara prior to dehulling produced moin-moin that compared favourably with moin-moin from fresh pastes (controls). Fresh paste of Bambara produced through manual dehulling resulted in moin-moin that compared similarly to conventional moin-moin from fresh cowpea. The proximate chemical compositions were not significantly affected by the treatments but functional properties were significantly affected.
\end{abstract} of the flours was also investigated. Both cold and hot

\section{INTRODUCTION}

$\mathrm{B}$ ambara nut belongs to the family of leguminosae. It is indigenous to the tropical Africa (Kay, 1979). Bambara is grown extensively in Nigeria (Oguntunde, 1985; Enwere, 1998) but it is one of the lesser utilised legume in Nigeria. Nigeria produced over 100,000 metric tonnes, closely followed by Niger with 30,000 metric tonnes and Ghana with 20,000 metric tonnes (Asiedu, 1989). In Nigeria, the freshly harvested pods are cooked, shelled and eaten as a vegetable snack, while dry seeds are either roasted and eaten as a snack(Kay, 1979; Alobo, 1999) or milled into flour and used in preparation of moin-moin (Olapade et al, 2005) analogy called 'okpa' among the Igbo tribe of Nigeria
Key words- Bambara nut, moin-moin, blanching, roasting, dehulling
(Enwere,1998). For most food uses, the seed coats of legumes including Bambara are removed to reduce the anti-physiological factors and fibre content, and this result in better appearance, texture, cooking quality, palatability and digestibility of the products (Akinjayeju and Enude, 2002). Dehulling can be accomplished manually or mechanically depending on the type of legume and/or quantity involved (Ehiwe and Reichert, 1987). Dehulling has been a limitation factor in the preparation of flour from Bambara that could produce acceptable moinmoin substitute most especially with respect to the texture and flavour. The conventional methods used always result into a product with a very hard texture 
and strong beany flavour (Alobo, 1999). Lack of knowledge of the functional, chemical and nutritional properties of some legumes grown in developing countries is responsible for their less utilisation in food formulations (Udensi et al, 1999). Bambara groundnut is a complete food and is eaten in various forms either immature or fully ripe. The seed is hard, smooth, usually round and varying in size up to about $1.5 \mathrm{~cm}$ in diameter (Kay, 1979). It can also vary in colour from white, cream, dark-brown, red or black and may be speckled or patterned with combination of these colours. This work, therefore, aims at investigating effect of different pre-treatments prior to dehulling on physico-chemical properties of the Bambara flours.

\section{MATERIALS AND METHODS Procurement of material}

Cream coloured variety of Bambara nut was procured from mile 12 market in Lagos State Nigeria.

\section{Preparation of bambara flours}

The seeds were thoroughly cleaned and sorted to remove extraneous matters. 200gram clean seeds was weighed into four different places, the first batch was steam blanched for $15 \mathrm{~min}$ (SBS), the second batch was steeped in water at room temperature $\left(28 \pm 2^{\circ} \mathrm{C}\right)$ for $8 \mathrm{~h}(\mathrm{CWS})$, the third batch was parboiled for $10 \mathrm{~min}$ (HBS). The three samples were later dried in air draught drier (Mermmet, Germany) at $65^{\circ} \mathrm{C}$ for $48 \mathrm{~h}$ to moisture content of about $10 \%$. The fourth batch (NTS) was roasted $\left(190^{\circ} \mathrm{C}\right)$ for $5 \mathrm{~min}$. The four samples were separately dehulled using plate mill with clearance of $6 \mathrm{~mm}$ between the plates. The cotyledons from each sample were separately milled into powder using a laboratory hammer mill to pass through $0.8 \mathrm{~mm}$ screen size. The samples were packed in high density polyethylene and stored under refrigeration $\left(4^{\circ} \mathrm{C}\right)$ for further analysis.

\section{Analyses}

100grammes of each batch was taking for manual separation. The seed coat and cotyledon were separately weighed using a top loading balance (Mettler, W. Germany). The dehulling-ability was expressed as percentage free seed coats from cracked beans. Proximate chemical composition of the samples was carried out according to official methods (AOAC, 1990). Bulk density, foaming capacity, foam stability and gelation capacity were done as previously described (Olapade et al, 2004). All tests were done in triplicate except otherwise stated.

\section{Preparation of moin-moin}

Fresh pastes were prepared from both cowpea and Bambara (figure 2) and reconstituted flours. Flours $200 \mathrm{~g}$ were each hydrated with $300 \mathrm{ml}$ water $\left(60^{\circ} \mathrm{C}\right)$ and allow standing for $1 \mathrm{~h} .200 \mathrm{~g}$ paste each was blended with red pepper $20 \mathrm{~g}$, fresh onion $20 \mathrm{~g}$, $10 \mathrm{~g}$ salt, $1 \mathrm{~g}$ mono-sodium-glutamate seasoning and $50 \mathrm{ml}$ warm vegetable oil $\left(60^{\circ} \mathrm{C}\right)$ in a Kenwood food blender at speed 3 for $4 \mathrm{~min}$. The mixture was dispensed into standard moin-moin aluminium cup and steamed for $45 \mathrm{~min}$ at ambient pressure.

\section{Sensory evaluation}

The moin-moin samples were coded and presented to a ten panel of judges who are familiar with the product for sensory evaluation. The trained panel scored the colour, flavour, taste, texture and overall-acceptability of the moin-moin using a nine point Hedonic scale, where 9 indicated extremely like and 1 extremely dislike.

\section{Statistical analysis}

Data obtained were statistically analysed and samples, means were separated using Duncan's multiple test procedure. 


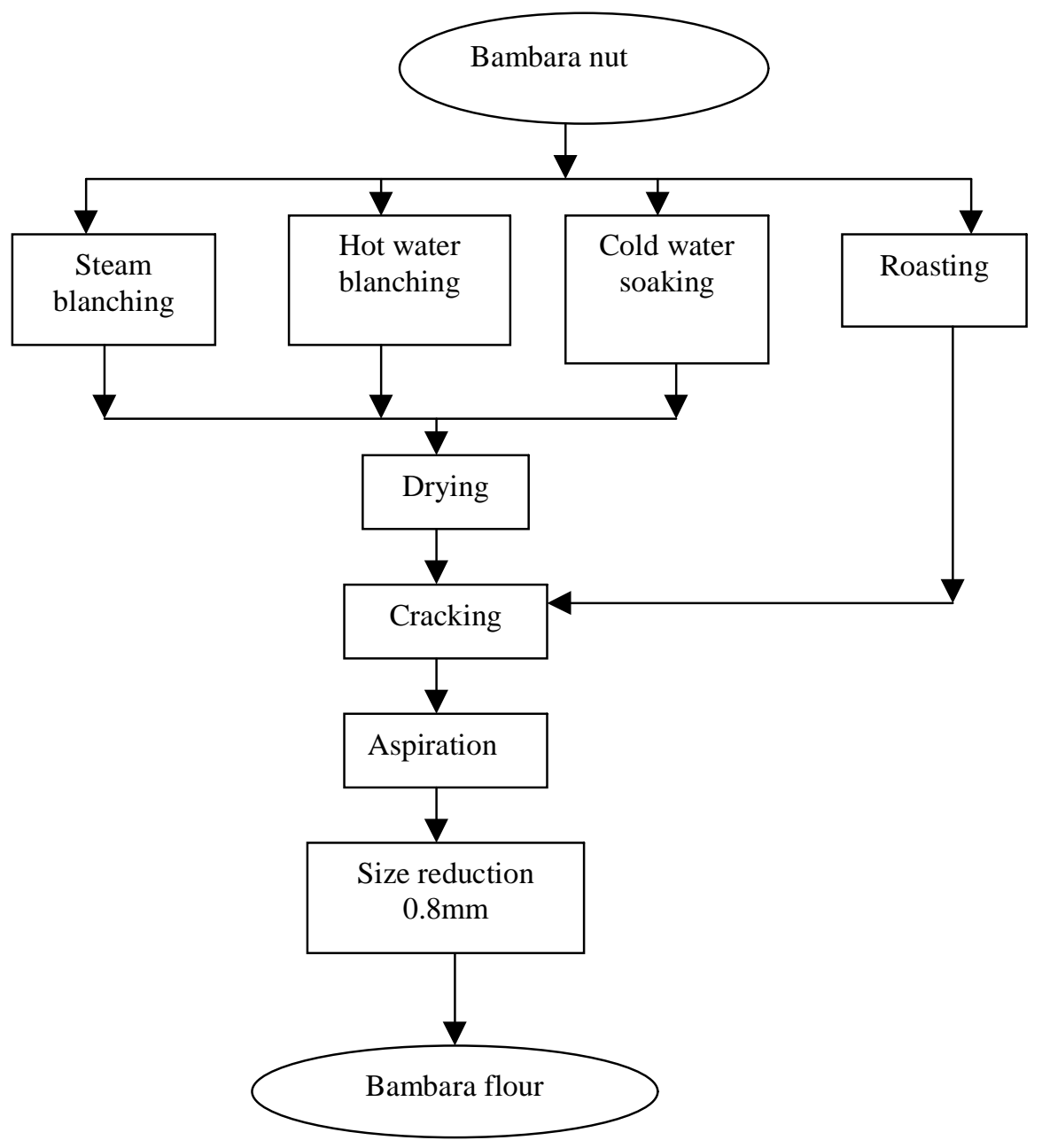

Fig1. Flow chart for different processes of preparation of bambar flour. 


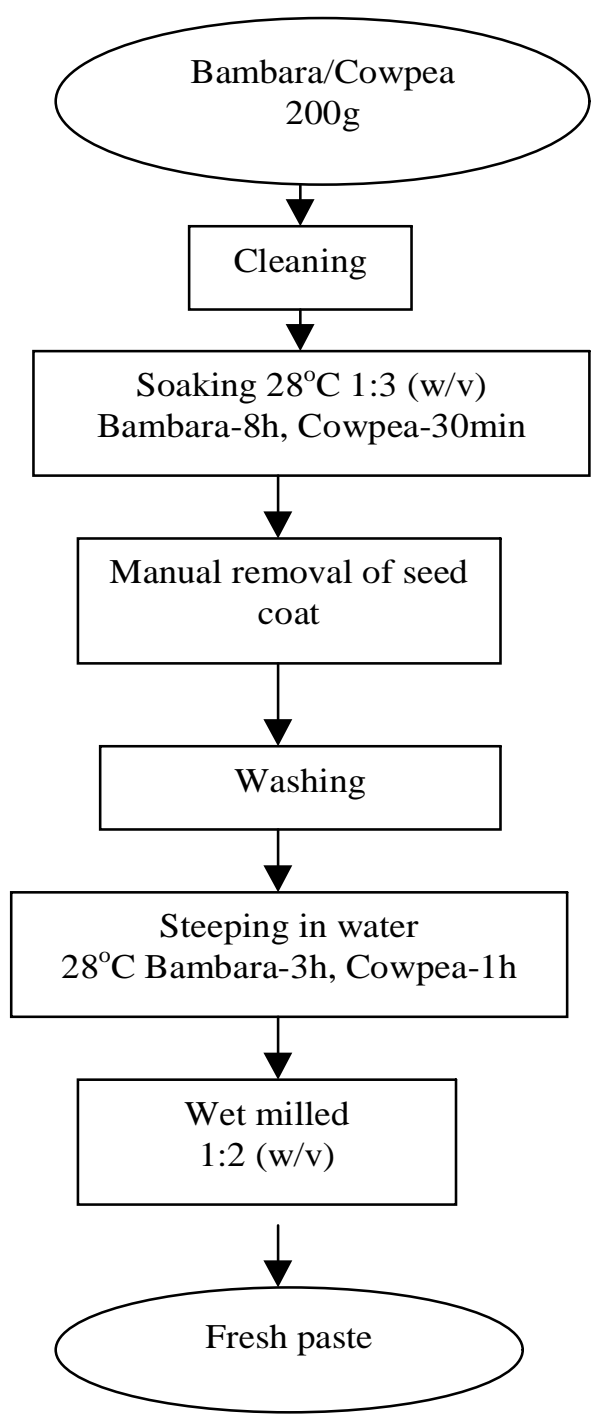

Fig 2. Flow diagram of preparation of fresh paste 


\section{RESULTS AND DISCUSSION}

The results of functional properties of bambara flours are presented in Table 1. Foam-ability value was highest for cold water soaked sample (21.6\%) while roasted sample showed the least value $(12.5 \%)$. The results agreed with the early report of Desphade et al (1982), which reported foaming capacity values of $26-41 \%$ for some dry beans and attributed foaming capacity to ability of the proteins to denature, precipitate and lower the surface tension at the air-liquid interface of the foam. Diwakar et al (1996) attributed foam-ability to the configuration of the protein molecules; flexible protein molecules give good foam-ability but highly ordered globular molecules give low foam-ability. Low foam-ability of roasted sample flour may be attributed to ordered globular molecules as a result of high temperature $\left(190^{\circ} \mathrm{C}\right)$ employed during roasting. The least concentration of the samples ranged from 12 to $>20 \%$. The results fall within those reported for some legumes (Henshaw and Shobowale, 1996; Abbey and Ibeh, 1988; Olapade et al, 2004). The higher the least gelation concentration the lower the ability of the flour to form a stable gel. There were significant differences among the samples means $(\mathrm{p}=0.05)$. Fleming et al, (1974) attributed gelation capacity of legume proteins to the globulin fraction. There were significant differences among samples means for bulk density $(\mathrm{p}=0.05)$. Dehull-ability values ranged from $4.7 \%$ to $15.7 \%$ for the flour samples. Cold water soaking results in highest dehullability value. Hanson (1975) attributed dehull-ability of legumes to the pectin content, which was regarded as the intercellular cementing substances between the cotyledons and the seed coats. The higher values of dehull-ability for treatment involving water soaking may be attributed to the weakening of the pectin substances.

The proximate chemical composition of the flours was essentially similar (Table 2) and within the range generally reported for bambara nut (Oyenuga, 1968). Crude protein values of the flours were not significantly different $(\mathrm{p}=0.05)$. The moisture content ranged from 10.7 to $12.0 \%$ for roasted sample and hot water soaked sample respectively. Fat content was generally higher compared to other non-oil seed legumes (5.03$7.06 \%)$

Table 1 presents the results of sensory evaluation of moin-moin samples from bambara and cowpea. Fresh paste from bambara produces moinmoin that is equally accepted in all attributes compared to moin-moin from fresh cowpea paste. The colour, flavour, texture, taste and overall acceptability scores of moin-moin from cold water steeped and hot water blanched bambara flour were rated similarly to those of moin-moin from fresh pastes (controls). Moin-moin from steam blanching treatment had low rated colour, flavour, taste, texture and overall acceptance. Roasted sample produced less firm moin-moin. This may be attributed to heat damage to its biopolymers constituents. Poor rating of the samples SBS and NTS could be attributed to their low dehull-ability and high least gelation concentration.

\section{CONCLUSION}

The study revealed that it is possible to produce acceptable moin-moin from Bambara nut. The moinmoin from Bambara flours were favourably scored compared to the control. Pre-soaking Bambara nut for dry dehulling gave better dehull-ability that resulted in more acceptable moin-moin.

\section{ACKNOWLEDGMENT}

The authors are greatly indebted to the management staff of Federal Institute of Industrial Research Oshodi, Lagos for the support received during the study. 


\section{REFERENCES}

Abbey B.W. and Ibeh G.O. (1988). Functional properties of raw and heat processed cowpea (Vigna unguiculata Walp) flour. Journal of Food Science 53 (6); 1775-1777

Alobo, A.P. (1999). Production and organoleptic assessment of Akara from Bambara groundnut (Voandzeia subterranean L. Thouars). Plant Foods for Human Nutrition 53. 313-320.

AOAC. (1990). Official methods of analysis. Association of Official Analytical Chemists, Washington DC., USA.

Akinjayeju O. and Enude, O.T. (2002). Effects of dehulling on some properties of cowpea (Vigna unguiculata Walp $L$.) flours. Italian Journal of Food Science. No 1, Vol 14. 53-58.

Asiedu J.J. (1989). Processing tropical crops: a technical approach. Macmillan Publishers Limited, London, p 1-10.

Coffman C.W. and Gracia, V.V. (1977). Functional properties and amino-acid content of a protein isolate from mung bean flour. Journal of Food Technology $12,473-484$.

Desphande S.S., Sathe S.K., Cornforth D. and Salunkhe D.K. (1982). Effects of dehulling on functional properties of dry bean (Phaseolus vulgaris $L$.) flours. Cereal Chemistry 59 (5); 397401.

Diwakar P., Kushwar A. and Kushwah H.S. (1996). Effect of processing on the functional properties of some local varieties of horse gram (Dolichos biflorus L.) in Madhya Pradesh. Journal of Food Science and Technology, 33 (2); 150-152.
Enwere N.J. (1998). Foods of plants origin: Processing and utilization with recipes and Technology profiles. Afro-orbis Publishers, Nsukka, Nigeria. p59-61.

Ehiwe A. and Reichert B.M. (1987). Variability in dehulling quality of cowpea, pigeon pea and mung bean cultivars. Cereal Chemistry. 64, 86

Fleming S.E., Sosulski F.W., Kilara A. and Humbert E.S. (1974). Viscosity and water absorption characteristics of slurries of sunflower and soybean flours, concentrates and isolates. Journal of Food Science, 39, 188

Hanson L.P. (1975). Commercial processing of vegetables. NJ, USA Noyes Data Corp, p.341

Henshaw F.O. and Shobowale M.K. (1996). Cowpea flour produced from different bean varieties: Functional properties, composition and acceptability of products. Nigerian Food Journal 14, 62-70

Kay D.E. (1979). Food legumes. Crop and product digest No. 1. London: TPI, p. 142.

Kulkarni, K.D., Kulkarni, D.N. and Ingle, U.M. (1991). Sorghum malt-based weaning food formulations: Preparation, functional properties and nutritive value. Food and Nutrition bulletin, Vol 13, No 4; 322-327.

Oguntunde A.O. (1985). Development of new food products from readily available raw materials. Paper present at the Nigerian Institute of Food science and Technology Training workshop Ibadan, Nigeria.

Olapade A.A., Ugokwe P.U., Ozumba A.U., Solomon H.M., Olatunji O. and Adelaja S.O. (2004). Physico-chemical properties of premixes for preparation of akara. Nigerian Food Journal Vol. 22, 54-59. 
Olapade A.A., Ozumba A.U., Solomon H.M., Udensi, E.A., Onwuka G.I. and Eze, A.I. (1999). Olatunji O. and Adelaja S.O. (2005). Rheological Effects of blanching and drying temperature on the properties and consumer acceptance of moin-moin functional properties of Bambara groundnut premix. Nigerian Food Journal Vol. 23, 144-147.

(Voandzeia subterranae). Proceedings of 23rd NIFST annual conference, 25-27 October, Abuja Oyenuga V.A. (1968). Nigeria's Foods and Feeding Nigeria, p191-192. stuffs: Their chemistry and nutritive value. Ibadan University Press, p109

Table 1- Functional properties of bambara flours.

\begin{tabular}{lccllc}
\hline Sample & $\begin{array}{l}\text { Foam-ability \% } \\
\text { \% (after 120 min.) }\end{array}$ & $\begin{array}{l}\text { Foam-stability } \\
\text { concentration \% }\end{array}$ & $\begin{array}{l}\text { Least gelation } \\
\text { density g/ml }\end{array}$ & $\begin{array}{l}\text { Bulk } \\
\text { ability \% }\end{array}$ & Dehulling-a \\
CWS & $21.5_{\mathrm{a}}$ & $3.0_{\mathrm{c}}$ & $12_{\mathrm{b}}$ & $0.625_{\mathrm{a}}$ & $15.7_{\mathrm{a}}$ \\
SBS & $17.5_{\mathrm{ab}}$ & $6.0_{\mathrm{b}}$ & $20_{\mathrm{a}}$ & $0.571_{\mathrm{ab}}$ & $9.5_{\mathrm{b}}$ \\
HBS & $13.75_{\mathrm{b}}$ & $2.5_{\mathrm{c}}$ & $12_{\mathrm{b}}$ & $0.500_{\mathrm{b}}$ & $12.9_{\mathrm{a}}$ \\
NTS & $12.5_{\mathrm{b}}$ & $7.5_{\mathrm{a}}$ & $>20_{\mathrm{a}}$ & $0.606_{\mathrm{a}}$ & $4.7_{\mathrm{c}}$ \\
\hline
\end{tabular}

Means with the same subscripts along the column are not significantly different $(p=0.05)$

CWS-Cold water soaked sample for $8 \mathrm{~h}$

SBS-Steam blanched sample

HBS-Hot water blanched sample

NTS-Roasted sample $\left(190^{\circ} \mathrm{C}\right)$

Table 2. Proximate composition of bambara flours

\begin{tabular}{|c|c|c|c|c|c|}
\hline Sample & Moisture \% & Crude protein \% & Ash \% & Fat $\%$ & Carbohydrate \% \\
\hline CWS & $11.33_{\mathrm{a}}$ & $19.11_{a}$ & $3.61_{\mathrm{a}}$ & 6.49 & 59.46 \\
\hline SBS & $11.83^{a}$ & $18.42^{\mathrm{a}}$ & $3.77^{a}$ & $5.81_{\mathrm{b}}^{\text {a }}$ & $60.17^{\mathrm{a}}$ \\
\hline HBS & $11.97^{\mathrm{a}}$ & $17.71_{\mathrm{b}}^{\mathrm{a}}$ & $3.96^{\mathrm{a}}$ & $5.03_{c}^{b}$ & $61.33^{\mathrm{a}}$ \\
\hline NTS & $10.70_{\mathrm{b}}^{\mathrm{a}}$ & $19.47_{\mathrm{a}}^{\mathrm{b}}$ & $3.99_{\mathrm{a}}^{\mathrm{a}}$ & $7.06_{a}^{c}$ & $58.78_{\mathrm{b}}^{\mathrm{a}}$ \\
\hline
\end{tabular}

Means with the same subscripts along the column are not significantly different $(p=0.05)$

CWS-Cold water soaked sample for $8 \mathrm{~h}$

SBS-Steam blanched sample

HBS-Hot water blanched sample

NTS-Roasted sample $\left(190^{\circ} \mathrm{C}\right)$ 
Table 3. Sensory evaluation of moin-moin from bambara flours

\begin{tabular}{l|l|l|l|l|c}
\hline Sample & Colour & Flavour & Taste & Texture & Overall-acceptability \\
\hline CWS & $7.7_{\mathrm{a}}$ & $6.5_{\mathrm{ab}}$ & $7.0_{\mathrm{ab}}$ & $6.0_{\mathrm{abc}}$ & $7.0_{\mathrm{ab}}$ \\
\hline SBS & $6.5_{\mathrm{b}}$ & $6.7_{\mathrm{ab}}$ & $6.1_{\mathrm{b}}$ & $5.3_{\mathrm{cd}}$ & $5.6_{\mathrm{c}}$ \\
\hline HBS & $6.7_{\mathrm{b}}$ & $6.7_{\mathrm{ab}}$ & $7.3_{\mathrm{a}}$ & $5.7_{\mathrm{bcd}}$ & $6.7_{\mathrm{b}}$ \\
\hline NTS & $5.2_{\mathrm{c}}$ & $5.2_{\mathrm{c}}$ & $5.3_{\mathrm{c}}$ & $5.3_{\mathrm{d}}$ & $5.4_{\mathrm{c}}$ \\
\hline CCS & $8.1_{\mathrm{a}}$ & $7.3_{\mathrm{a}}$ & $7.7_{\mathrm{a}}$ & $7.3_{\mathrm{a}}$ & $7.7_{\mathrm{a}}$ \\
\hline BCS & $8.0_{\mathrm{a}}$ & $7.3_{\mathrm{a}}$ & $7.7_{\mathrm{a}}$ & $7.0_{\mathrm{a}} \mathrm{b}$ & $7.3_{\mathrm{ab}}$ \\
\hline
\end{tabular}

Means with the same subscripts along the column are not significantly different $(P=0.05)$

CWS-Cold water soaked sample for $8 \mathrm{hr}$.

SBS- Steam blanched sample

HBS- Hot water blanched sample

NTS-Roasted sample $\left(190^{\circ} \mathrm{C}\right)$ 